\title{
Evaluation of Biofilm Induced Urinary Infection Stone Formation in a Novel Laboratory Model System
}

\section{Authors: Trace Hobbs, Logan N. Schultz, Ellen G. Lauchnor, Robin Gerlach, \& Dirk Lange}

NOTICE: this is the author's version of a work that was accepted for publication in The Journal of Urology. Changes resulting from the publishing process, such as peer review, editing, corrections, structural formatting, and other quality control mechanisms may not be reflected in this document. Changes may have been made to this work since it was submitted for publication. A definitive version was subsequently published in The Journal of Urology, [Vol. 199, Issue No. 1, January 2018] DOI\#10.1016/j.juro.2017.08.083

Hobbs T, L.N. Schultz, E.G. Lauchnor, R. Gerlach, D. Lange, "Evaluation of Biofilm Induced Urinary Infection Stone Formation in a Novel Laboratory Model System," The Journal of Urology 199, no 1, (January 2018): 178-185. 


\title{
Evaluation of Biofilm Induced Urinary Infection Stone Formation in a Novel Laboratory Model System
}

\author{
Trace Hobbs, Logan N. Schultz, Ellen G. Lauchnor, Robin Gerlach, and \\ Dirk Lange
}

\begin{abstract}
Abbreviations
and Acronyms

AU 1/4 artificial urine

BA $1 / 4$ bladder analog

BE $1 / 4$ BA effluent

BI $1 / 4$ BA influent

FE-SEM $1 / 4$ field emission

SEM KA $1 / 4$ kidney analog

KE $1 / 4$ KA effluent

KI $1 / 4 \mathrm{KA}$ influent

LB $1 / 4$ Luria-Bertani

SEM 1/4 scanning electron microscopy
\end{abstract}

XRD 1/4 X-ray powder

diffraction
Purpose: Infection stones, which comprise approximately $15 \%$ of all urinary tract stones, are induced by infection with urease-positive pathogens. The bacteria in the stone matrix present significant treatment impediments compared to meta-bolic kidney stones. While much is known about how urinary composition reg-ulates metabolic stone formation, there is a general lack of knowledge of which urinary factors regulate the rate of infection stone formation. Unfortunately more in-depth research into infection stones is limited by the lack of suitable models for real-time study of bacterial biofilm formation and stone formation under varying conditions.

Materials and Methods: We developed an in vitro model to study infection stone formation. The model closely represents the processes that occur in vivo, including the observed migration of ureolytic bacteria (our culture of Proteus mirabilis) from the bladder to the kidneys, followed by biofilm and stone formation in the kidney. We used scanning electron and confocal laser micro-scopy, x-ray diffraction, biological counts and dissolved chemical analyses to evaluate the model system.

Results: Crystals that formed in the system resembled clinically removed stru-vite stones in structure and composition. Results showed that the degree of ureolysis required to significantly change urine $\mathrm{pH}$ was minimal, bacterial communities inhabited the ureter, and upstream colonization and struvite formation required lag time.

Conclusions: These results have implications for the detection and treatment of struvite stones. Currently this model is being used to study specific urinary factors that regulate struvite formation to identify treatment options, which combined with antibiotics would improve treatment of these stones and decrease recurrence.

Key Words: kidney calculi, struvite, crystallization, Proteus mirabilis, in vitro techniques

UROLITHIASIS, or mineral formation, in the urinary tract is the underlying cause of kidney stone disease, a debilitating condition affecting about 10\% (740 million) of the world popu-lation and resulting in significant patient morbidity and high costs to health care systems. 1 Furthermore, at least $50 \%$ of first time stone for-mers have recurrent stone episodes within 10 years. 2 Urologists are especially challenged by stones formed by infections, which comprise approximately $15 \%$ of kidney stones 3 
and are caused by urease-positive microbes, including Proteus, Staphylococcus, Pseudomonas, Providencia and Klebsiella. ${ }^{4-6}$ Infection stones are composed of struvite $\left(\mathrm{NH}_{4} \mathrm{MgPO}_{4} \cdot 6 \mathrm{H}_{2} \mathrm{O}\right)$ and apatite $\left(\mathrm{Ca}_{5}\left[\mathrm{PO}_{4}\right]_{3}(\mathrm{OH}, \mathrm{F}, \mathrm{Cl}) \text { or } \mathrm{Ca}_{10}\left(\mathrm{PO}_{4}\right)_{6} \mathrm{CO}_{3}\right)^{7-9}$ and can grow rapidly during 4 to 6 weeks into large staghorn stones. If left untreated, such infections and subsequent stone formation can result in kidney failure. ${ }^{10}$

Struvite stones do not form in all patients with urease-positive infections so that understanding the role of urine chemistry and other bacteria independent factors on struvite stone formation is important. ${ }^{5}$ Much is known about the role of urine chemistry on metabolic stone disease, which is a key factor in guiding therapy. However, struvite stones are less understood. Studying the interplay among bacterial biofilm formation, urine composition and struvite stone formation will identify parameters to improve treatment.

In vitro systems to study abiotic calcium oxalate precipitation and inhibition were developed previously, including a 2 reactor system. ${ }^{11,12}$ In vitro flow systems are also commonplace in studies of biofilm formation and encrustation on urinary devices. ${ }^{13-15}$ Notably an artificial bladder system was developed to specifically study the dynamics of microbial colonization and mineralization. ${ }^{16}$ However, research on struvite stone formation has been limited to date due to the lack of in vitro models that specifically facilitate the study of factors affecting struvite precipitation and growth, including urine composition, while maintaining realistic flow conditions of the urinary tract.

In this study we developed a laboratory model to represent the urinary tract and enable the control of biofilm induced stone formation in different urine chemistries, microbes and flow rates. The model facilitates the visualization of microbe-mineral interactions in real time, enabling us to make clinically relevant observations about the events leading from initial cystitis to the development of kidney infection and struvite stone formation.

\section{METHODS}

\section{Laboratory Model}

The in vitro system consisted of a reservoir with fresh AU, a KA, a ureter analog, a BA and a waste reservoir (fig. 1). The CDC Biofilm Reactor ${ }^{\circledR},{ }^{17}$ which simulates kidney and bladder reservoirs, consists of a stirring vane and 8 suspended coupon holders attached to the reactor lid and provides 24 disk-shaped coupons for the periodic sampling of attached bacteria and precipitates (fig. 1). Supplementary figure 1 (http://jurology.com/) shows the coupons and the glass capillary before and after experiment termination, demonstrating biofilm growth and
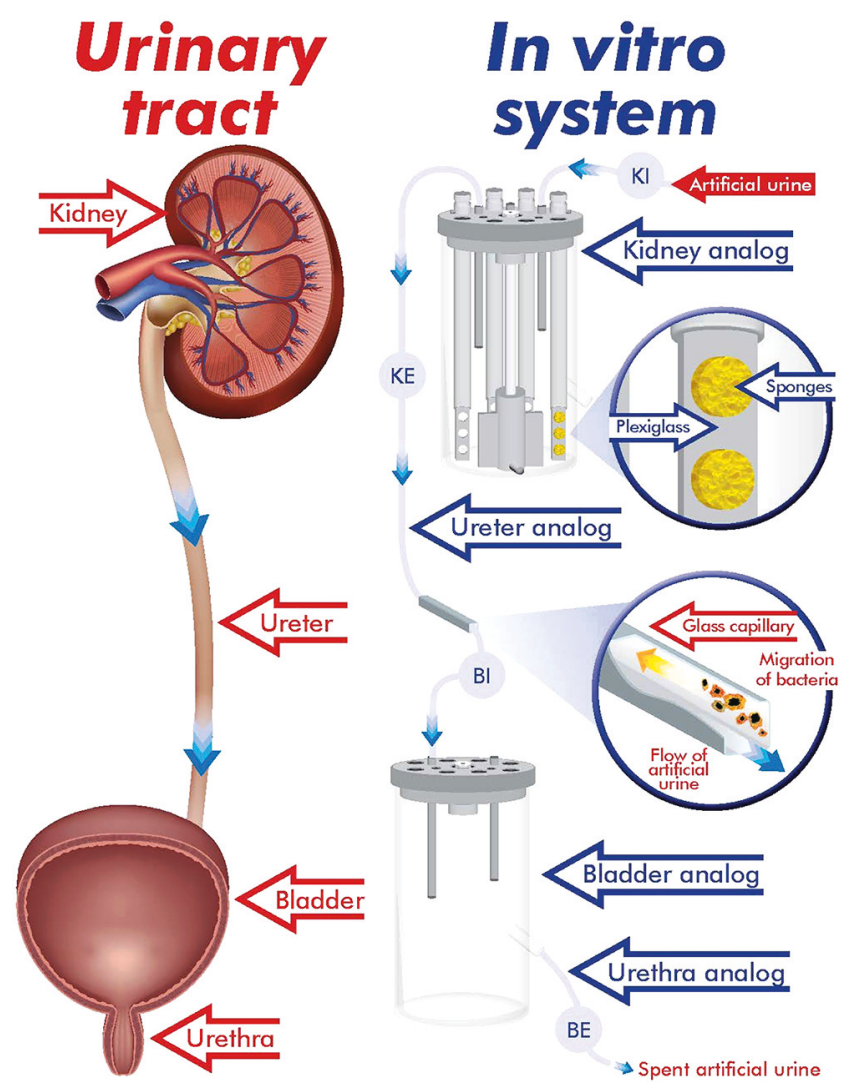

Figure 1. Laboratory model and human urinary tract. $\mathrm{KI}, \mathrm{KE}, \mathrm{BI}$ and $B E$ indicate approximate locations of sampling ports in laboratory model system. Pumps are located on $\mathrm{KI}$ line and $\mathrm{AU}$ travels from kidney to bladder by gravity draining. Arrows indicate direction of flow through systems. Top inset, schematic of coupon holder and 2 sponge coupons (yellow images). Sponge coupons can be replaced with Plexiglas or other materials. Bottom inset, schematic of $1 \times 1 \mathrm{~mm}$ square cross-section glass capillary used to visualize biofilm growth and mineral accumulation by confocal laser scanning microscopy (supplementary fig. 1, http://jurology.com/).

precipitate accumulation. The coupon materials used were $1.27 \mathrm{~cm}$ diameter Plexiglas ${ }^{\circledR}$ and sponge coupons of Scotch-Brite ${ }^{\circledR}$ Heavy Duty Scrub Sponges cut to $1.3 \times$ $0.5 \mathrm{~cm}$. The sponge coupons can provide a nidus for stone formation, and a safe and porous environment for bacteria.

Fresh AU was pumped into the reactor and an overflow port in the KA ensured a constant volume of $350 \mathrm{ml}$. Size 16 Masterflex ${ }^{\circledR}$ silicone tubing was used to connect the $\mathrm{KA}$ to the $\mathrm{AU}$ reservoir as the influent line and the $\mathrm{BA}$ via the ureter analog line. In some experiments a $10 \mathrm{~cm}$ $1 \mathrm{~mm}^{2}$ glass capillary was inserted in the ureter line to facilitate real-time biofilm and mineral imaging in the ureter. Peristaltic pumps (Cole-Parmer $\left.{ }^{\circledR}\right)$ were used to control all fluid flow through the system. A flow break in the influent line prevented contamination of the influent AU.

Sampling ports were inserted in the KI and ureter lines (KE and BI). Size 25 Masterflex silicone tubing was used to connect the overflow port of the BA reactor to a 
waste container to allow for sampling of the BA reactor effluent (BE). The entire system was contained in an incubator and maintained at a mean $\pm \mathrm{SD} 37 \mathrm{C} \pm 1 \mathrm{C}$.

\section{Bacterial Cultivation}

LB medium (25 gm/l) was inoculated with Proteus mirabilis SWRC 124 from a frozen stock culture (1:100) and incubated at $37 \mathrm{C}$ on a horizontal shaker at $150 \mathrm{rpm}$. P. mirabilis is a common urinary tract pathogen. ${ }^{8}$ After 24 hours $100 \mathrm{ml}$ fresh LB were inoculated (1:1,000) with culture and incubated as described. The culture was washed 3 times by centrifugation at 4,300 $\times$ gravity and resuspended in phosphate buffered saline composed of $8.5 \mathrm{gm} / 1 \mathrm{NaCl}, 0.61 \mathrm{gm} / 1 \mathrm{KH}_{2} \mathrm{PO}_{4}$ and $0.96 \mathrm{gm} / 1 \mathrm{~K}_{2} \mathrm{HPO}_{4}$ before being diluted to an optical density at $600 \mathrm{~nm}$ of 0.4 in phosphate buffered saline and used as inoculum of approximately $10^{8} \mathrm{cfu} / \mathrm{ml}$. AU was prepared as previously described $^{18}$ and added to the media reservoir following filter sterilization.

\section{Laboratory System}

Components of the laboratory system were autoclaved before adding specific volumes to each reservoir (350 $\mathrm{ml}$ in the $\mathrm{KA}$ and $100 \mathrm{ml}$ in the BA) and the silicone tubing connecting the components. The KA was placed on a stir plate at $150 \mathrm{rpm}$. A 22 gauge needle was used to inoculate the BA with $100 \mu \mathrm{l}$. mirabilis culture via a rubber stopper in the lid. AU flow was started immediately after inoculation and maintained throughout the experiment at 1.0 and $0.4 \mathrm{ml}$ per minute into the $\mathrm{KA}$ and the $\mathrm{BA}$, respectively. To simulate periodic urination the BA was emptied every 4 hours between 8:00 am and 8:00 pm, leaving a residual volume of approximately $25 \mathrm{ml}$. A $3 \mathrm{ml}$ sample was taken every 24 hours and coincided with BA emptying. AU exiting the BA served as the effluent sample. Remaining samples were obtained via the sampling ports using a plastic syringe and a 22 gauge needle.

Approximately $1 \mathrm{ml}$ of each sample was used for $\mathrm{pH}$ measurement using a VWR ${ }^{\circledR}$ sympHony ${ }^{\mathrm{TM}}$ meter with an Orion $^{\mathrm{TM}}$ double junction $\mathrm{pH}$ electrode. Another $1 \mathrm{ml}$ subsample was used for cfu determination via drop plating on LB agar. The remaining sample was filtered through a $0.2 \mu \mathrm{m}$ cellulose acetate syringe filter, diluted 1:5 and 1:10 in deionized water and refrigerated before dissolved chemistry measurements.

At predetermined times coupon holders were removed from the KA to assess biofilm and mineral accumulation. Each removed coupon holder was replaced with a sterile rubber stopper. After rinsing with deionized water the coupons were removed and stained with a LIVE/DEAD ${ }^{\mathrm{TM}}$ BacLight $^{\mathrm{TM}}$ Bacterial Viability Kit as described. Coupons that were not stained were dried for 24 hours before analysis.

\section{Chemical and Mineralogical Analyses}

Urea was measured using the Jung assay modified for 96-well plates. ${ }^{19}$ Triplicate $10 \mu$ l aliquots of samples and standards were added to wells of a 96-well plate followed by $125 \mu \mathrm{l}$ of each Jung assay reagent. The plate was incubated at $37 \mathrm{C}$ for 30 minutes before reading absorption at $505 \mathrm{~nm}$ with a Synergy ${ }^{\mathrm{TM}}$ HT Multi-Mode Microplate Reader and Gen5 ${ }^{\mathrm{TM}}$ software.
For XRD solids were scraped from air-dried coupons and from the inside of the reactors. After grinding them into a fine powder acetone was used to transfer the material to glass slides before analysis using an X1 XRD spectrometer (Scintag, Cupertino, California).

Confocal laser scanning microscopy was performed to visualize hydrated biofilms, minerals and sponge material. Coupons were stained with a LIVE/DEAD BacLight Bacterial Viability Kit for 15 minutes with SYTO-9 and propidium iodide $(6 \mu \mathrm{l} / \mathrm{ml}$ for Plexiglas and $3 \mu \mathrm{l} / \mathrm{ml}$ for sponges) before fluorescence imaging with a DM6000 CS confocal laser scanning microscope (Leica $\left.{ }^{\circledR}\right)$. Threedimensional images were collected from each coupon and processed with IMARIS, version 8.0.1 (http://www. bitplane.com/). After repeated rinsing any cells or minerals observed on the polycarbonate or the sponge coupons were assumed to be strongly adhered.

FE-SEM combined with energy dispersive x-ray spectroscopy was done to observe mineral shapes and near surface chemistry. Air-dried Plexiglas coupons were fixed to a SEM sample mount with carbon tape while sponge coupons were pressed against a SEM sample mount covered with carbon tape, leaving solid material attached to the tape. Clinical struvite stones were sectioned with sterile razor blades and fixed on the carbon tape on a SEM sample mount. Samples were sputter coated with iridium and imaged with a SUPRA ${ }^{\mathrm{TM}}$ 55VP FE-SEM. Elemental analysis was performed by energy dispersive $\mathrm{x}$-ray spectroscopy.

To remove the outermost layers of mineral precipitates and image underlying structures the samples were immersed in $5 \% \mathrm{HNO}_{3}$ for 5 seconds followed by a 10 -second rinse in deionized water before being dried for at least 1 hour and imaged by FE-SEM. The dissolution of small amounts of minerals enabled encased bacterial cells to be visualized.

\section{RESULTS}

\section{Comparison of In Vitro Precipitates with Clinical Struvite Stones}

To validate the translational potential of our model to clinical struvite stones we compared precipitates from KA and BA to surgically removed infection stones. Based on FE-SEM imaging and XRD analysis clinically obtained infection stones (in vivo) showed elemental compositions, mineral morphologies and phases similar to samples from the laboratory systems (in vitro) (figs. 2 and 3). Phosphorus comprised at least $8 \%$ of the total elements detected in all analyzed structures (fig. $2, D$ ). In the in vivo and in vitro samples larger crystals contained about a 1:1 stoichiometric ratio of magnesium to phosphorus and were shaped in the orthorhombic system of struvite (supplementary figs. 2 to 4 , http:// jurology.com/, and fig. 2). ${ }^{20}$ These crystals had a low calcium-to-magnesium ratio of approximately 1:10, suggesting more struvite than calcium containing minerals. A calcium-to-phosphorus ratio of approximately 1:1 was measured in smaller 

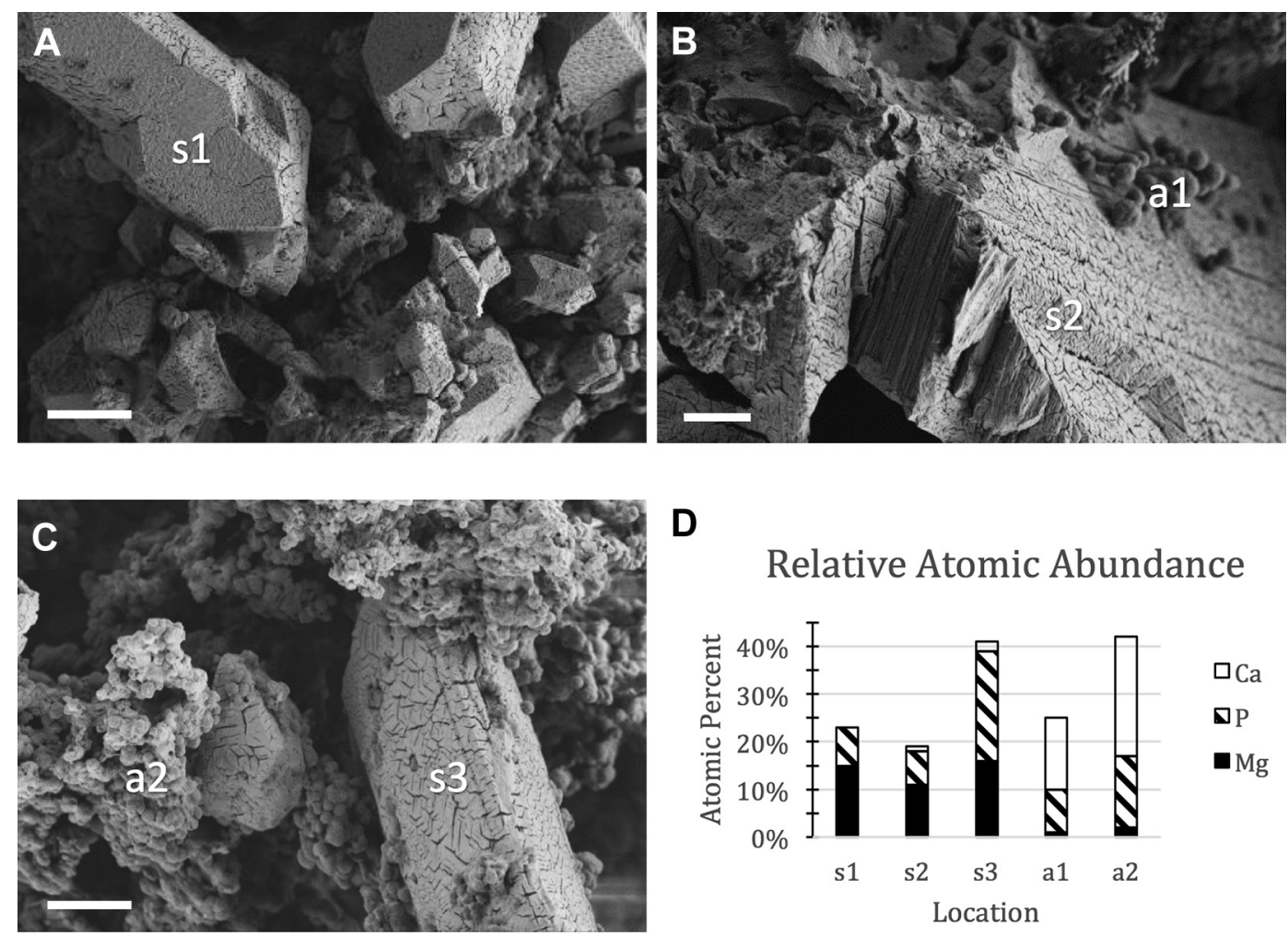

Figure 2. SEM micrographs of minerals produced in urinary flow system. $A$ and $C$, representative images of crystals formed in flow system on day 12 . $B$, clinically obtained infection stone sample. Scale bars indicate $10 \mu \mathrm{m}$. $D$, relative abundance of calcium, phosphorus and magnesium as fraction of total elements detected at each spot. Calcium, phosphorus, magnesium and oxygen contributed at least $97 \%$ of observed atomic abundance at each location. Oxygen represented vast remainder of elements detected at all locations (data not shown). X-axis labels correspond to s1 $(A), \mathrm{s} 2$ and $\mathrm{a} 1(B)$, and s3 and a2 $(C)$ indicating where spectra were obtained.

spherical structures with morphological characteristics of apatite stones (supplementary figs. 2 and 3 , http://jurology.com/ and fig. 2). This was supported by the approximately 10:1 calcium-to-magnesium ratio.
Furthermore, XRD spectra of KA samples suggested apatite $\left(\mathrm{Ca}_{5}\left(\mathrm{PO}_{4}\right)_{3}, \mathrm{X}\right)$ phases such as hydroxyapatite and carbonate apatite (supplementary fig. 2, http://jurology.com/). Carbonate apatite is commonly found in struvite stones. $^{7}$ Similarly
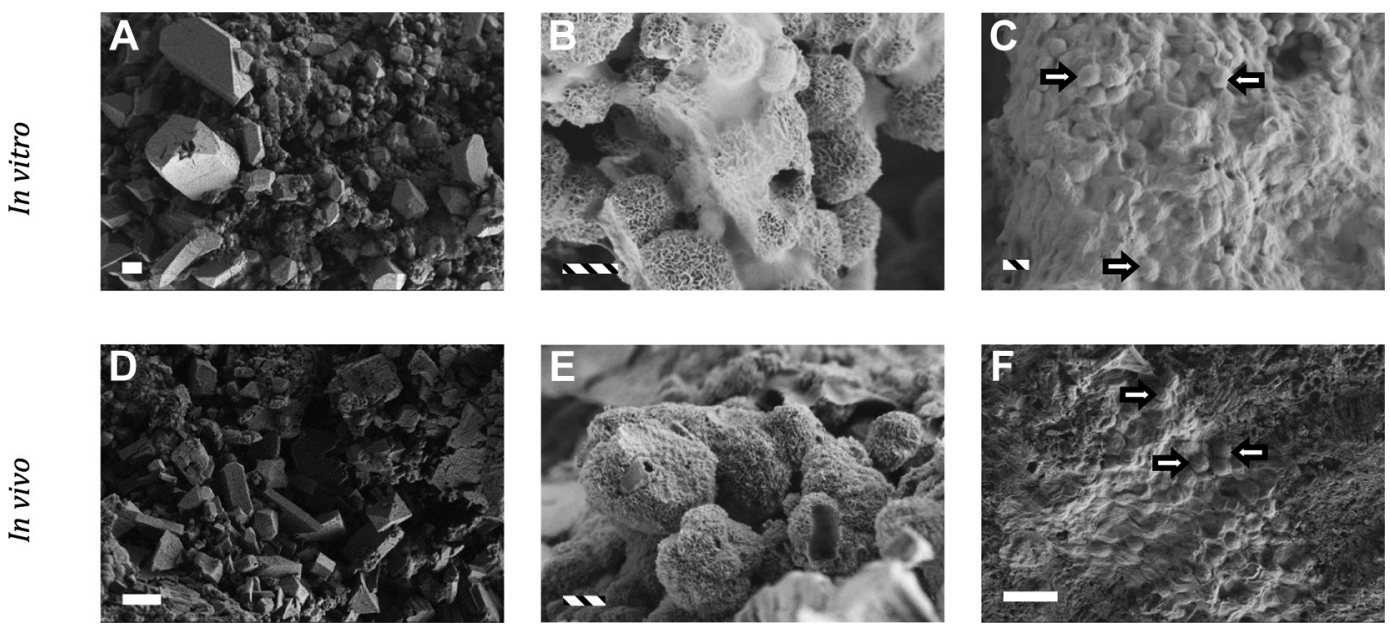

Figure 3. SEM micrographs of minerals in the laboratory system. $A$ to $C$, crystals formed in in vitro flow model. $D$ to $F$, clinically obtained infection stone samples. $A$ and $D$, similar structure and distribution of crystals and amorphous material. $B$ and $E$, similar size and shape of spherical particles. $C$ and $F$, potential microbial cells (arrows). Scale bars indicate $10(A, D$ and $F)$ and $1 \mu \mathrm{m}(B, C$ and $E)$. 
XRD patterns of clinical infection stones indicated struvite and apatite, in addition to calcium oxalate $\left(\mathrm{Ca}\left(\mathrm{C}_{2} \mathrm{O}_{4}\right) \cdot \mathrm{H}_{2} \mathrm{O}\right)$ (supplementary fig. 4, http:// jurology.com/).

In addition to mineral composition, the in vitro and in vivo samples showed crystals of similar shape and as typical for struvite (fig. $3, A$ and $D$ ). Apatite shaped minerals were detected in each sample type with similar size and structure (fig. $3, B$ and $E$ ). Acid etching of in vivo and in vitro samples revealed objects of sizes and shapes characteristic of P. mirabilis ${ }^{21}$ indicating a similar bacterial localization in the in vitro crystals and the clinical stones (fig. 3, $C$ and $F$ ).

\section{Aqueous Chemistry}

Samples were taken daily at the influent and effluent of the KA and BA. Successful inoculation of P. mirabilis was indicated by a $\mathrm{pH}$ increase from 6.8 to 8.8 and an increase from approximately $6.5 \times 10^{6}$ to $7.2 \times 10^{7} \mathrm{cfu} / \mathrm{ml}$ in $\mathrm{BE}$ within 1 day (fig. $4, A$ ). The urea concentration did not differ significantly with time (fig. 4, $B$ ). Bacterial migration was indicated by cfus in the KA effluent on day $2\left(6 \times 10^{6} \mathrm{cfu} / \mathrm{ml}\right)$, which increased to $5 \times 10^{7} \mathrm{cfu} / \mathrm{ml}$ by day 11 , similar to the number of bacteria in the bladder analog

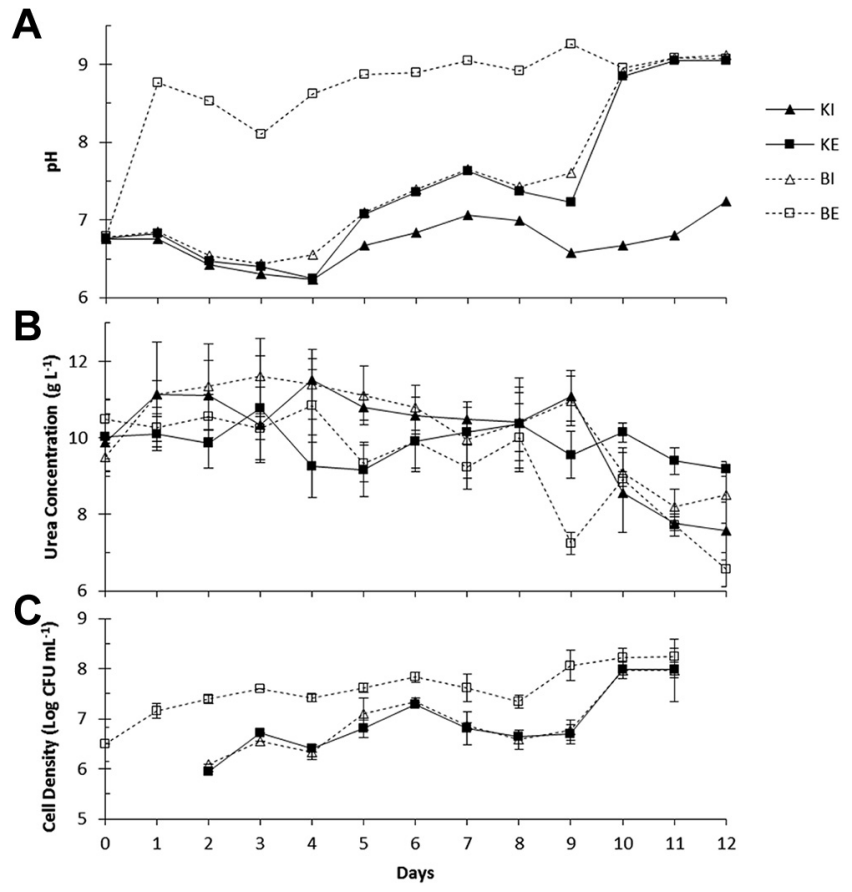

Figure 4. Select aqueous chemistry data from different points in laboratory model simulating human urinary tract (fig. 1). KI, AU medium. $A, \mathrm{pH}$, which was measured only once per sample. $B$, urea concentration. $C$, cell concentration represented as log of cfu. In $\mathrm{KI}$ throughout experiment and in $\mathrm{KE}$ and $\mathrm{BI}$ until day 2 cfu were not detectable. Error bars represent 1 SD of triplicate measurements and were less than marker if not visible. (fig. 4, A). Initial $\mathrm{pH}$ in the bladder and kidney analogs was 6.8 , which increased to $\mathrm{pH} 8.8$ by days 1 and 11, respectively (fig. 4, $C$ ).

\section{Imaging Biofilms during Stone Formation}

The model enables the noninvasive visualization and analysis of bacteria and minerals on coupons in the kidney analog with time. Figure 5 shows biofilm and struvite formation in the same experiment. Figure 4 shows those data. Fluorescence microscopy revealed that the sponge material in the kidney analog absorbed SYTO-9 stain but the sponge could be differentiated for cells, which had higher signal intensity from SYTO-9 binding to DNA (fig. 5, $A$ ). On days 4 and 5 minerals were not observed (fig. 5 , $A$ and $B$ ). However, on day 8 after bladder inoculation precipitates and bacterial biofilm completely covered the sponge material with larger minerals visible on days 10 and 12 (fig. $5, C$ to $E$ ). The progression of biofilm and mineral formation was consistent among separate experiments (fig. 5), demonstrating the consistency of the model. A similar association was observed in the glass capillary inserted in the ureter tubing, suggesting potential colonization as part of the migratory mechanism of $P$. mirabilis (fig. $5, F$ ). The proportion of green to red areas, representing living and dead bacteria, respectively, varied throughout the experiment. It generally decreased with time but remained greater than 1 based on microscopic observations.

\section{DISCUSSION}

Struvite stones form in the kidneys or elsewhere in the urinary tract due to infection with ureasepositive microbes. Given the intrastone localization of bacteria, fragments that remain postoperatively can serve as a nidus for repeat infection and recurrent stone episodes. While much is known about urinary conditions that promote metabolic stones, it is still unclear what urinary tract chemistries might promote or reduce the likelihood of struvite formation. Considering that stone size varies significantly among patients from few $\mathrm{mm}$ to staghorn calculi and struvite stones do not form in all patients infected with urease-positive bacteria, urine composition is likely to influence struvite formation. Investigations of the effect of urine chemistry have been limited by the lack of reliable in vitro models which represent the clinical events leading to struvite stone formation.

Our model represents the human urinary system spatially and physiologically in terms of flow characteristics. Its usefulness as a realistic model in which to study struvite stone formation was validated. SEM and XRD data showed that formed 

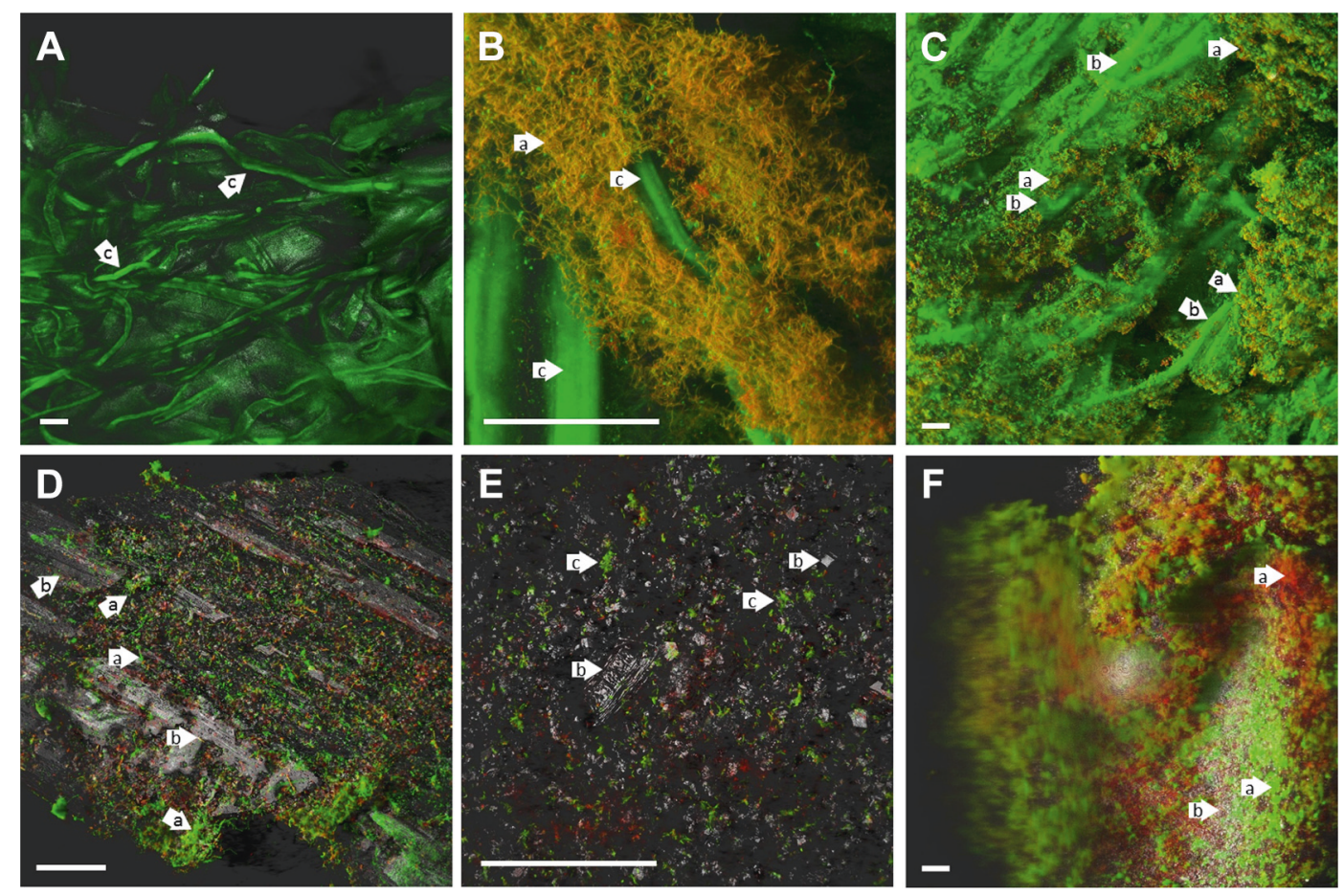

Figure 5. Confocal microscopy images of kidney analog of laboratory model experiment (fig. 4). $A$, sterile sponge coupon. $B$, sponge coupons sampled during experiment on day 5 . $C$, sponge coupons sampled during experiment on day 8 . $D$, sponge coupons sampled on day 10. $E$, sponge coupons sampled on day 12. $F$, inside of glass capillary inserted in ureter line, which was done on day 7 . Green areas indicate live microbial cells or sponge strands, which also stained green but are larger and more continuous than bacterial cells. Red areas indicate dead cells and extracellular nucleic acid. Gray areas indicate reflective material, including minerals but likely not biomaterial. Arrows labeled with a indicate microbial cells. Arrows labeled with $\mathrm{b}$ indicate minerals. Arrows labeled with $\mathrm{c}$ indicate sponge. LIVE/DEAD staining, scale bars represent $100 \mu \mathrm{m}$.

crystals had the same chemical composition and physical structure as clinical stones and stone compositions reported in the literature. ${ }^{22-24}$

Since struvite stone formation is driven by increased urinary $\mathrm{pH}$ due to ureolysis, we would expect a decrease in the overall urea concentration with increasing urine $\mathrm{pH}$. Interestingly this was not observed. While this may indicate limited sensitivity of the Jung urea assay, it also suggests that a significant change in urine $\mathrm{pH}$ associated with struvite formation requires minimal ureolysis. Geochemical modeling using PHREEQC ${ }^{25}$ (data not shown) confirmed that the amount of urea hydrolysis required to substantially increase the $\mathrm{AU} \mathrm{pH}$ is low at approximately $1 \mathrm{gm} / \mathrm{l}$. This explains why $\mathrm{pH}$ changes rather than changes in urea concentration are a more sensitive indicator of ureolytic infection.

In clinical practice aqueous urine chemistry measurements are critical in the diagnosis of struvite stones because preoperative observations of urinary biofilm or mineral formation are almost impossible. $^{26}$ The most reliable predictor is still stone culture but the stones cannot be obtained preoperatively unless the patient passes small fragments.
The observed increase in $\mathrm{pH}$ and cfu in BI and $\mathrm{KE}$ on day 5 indicates migration of $P$. mirabilis from the bladder to the kidney, which is the clinical sequence of events that results in kidney infections. Interestingly the number of planktonic (freely swimming) bacteria in the BI and the KE remained below the initial cfu in the bladder analog for about 8 days (fig. 4, $C$ ), suggesting a lag in upstream bacterial colonization. This may have been the direct result of an equilibrium between the bacterial growth rate and the rate at which urine flow removes bacteria. Similarly SEM analysis did not reveal a significant number of adherent bacteria on the sponge sections that were analyzed until day 5 despite planktonic bacteria in the KA.

These data may suggest that a critical bacterial number in the kidney is required prior to effective colonization and biofilm formation. This quasi constant bacterial number may represent an infection driven by biofilm colonization with the number of bacteria in the biofilm increasing with time while the number of planktonic bacteria free to form new microcolonies remains approximately constant. The possibility that most bacteria associated with struvite production might be biofilm associated rather 
than planktonic agrees with previous studies of urinary tract infection ${ }^{8}$ and is highly clinically relevant. It may explain why pathogens which cause struvite are often not isolated from urine cultures and provides an explanation of why stone cultures are more accurate for identifying the struvite producing species. This also illustrates the importance of targeted postoperative (eg antibiotic) treatment to be tailored against the specific microbes identified from stone cultures, molecular analysis or other methods of detection.

Furthermore, a time frame during which most bacteria in the kidney might be in the planktonic form rather than the biofilm form after the initial infection event suggests that a window may exist to effectively eradicate potential urease-positive pathogens from the kidney since bacteria are significantly more susceptible to antibiotic treatment in the planktonic form. ${ }^{27}$ Identifying this window may be difficult, given the delay between the onset of symptoms following bacterial colonization and the initiation of biofilm formation.

Collectively our observations support a hypothesis similar to that for indwelling urinary devices, which is that biofilm and struvite develop in stages, mainly by bacterial attachment, microcrystalline growth and the accumulation of abundant crystals. ${ }^{28}$ Visualization of small areas of biofilm containing crystal along the ureter analog via the inserted glass capillary suggested that these islands may form as part of bacterial migration to the kidneys, facilitating migration between the bladder and the kidneys. Previous studies demonstrated that $P$. mirabilis isolates from the ureters of infected mice expressed the same fimbriae that are important for bladder and kidney colonization, suggesting that colonization in the ureter is not unrealistic. ${ }^{29,30}$ While this hypothesis is plausible, it and any potential mechanisms identified using this model must be verified in in vivo models. The materials used only represent the urinary system spatially and do not consider the role of tissue specific characteristics and interactions in struvite stone formation.

\section{CONCLUSIONS}

The current model will allow for detailed study of specific bacteria-crystal interactions, which is important to develop an understanding and effective treatment of urinary tract stones. This model was developed to represent the reactions and transport dynamics of the urinary tract during infection and not to mimic specific surface interactions between the biofilms and biological tissue or other in vivo factors. The laboratory model facilitated time and space resolved sampling of biofilms and minerals in a simulated urinary tract, specifically demonstrating migration of microbes from bladder to kidney, biofilm growth, ureolysis and struvite precipitation. Mineral and biofilm morphologies closely resembled those of clinical stones, thus, validating model use to study clinically relevant factors that affect infection stone formation.

Future investigations will focus on fluorescently labeled bacteria to study specific bacteria-crystal interactions and the application of Raman microspectroscopy in time course investigations of biofilm and mineral formation in the artificial urinary tract to better understand specific steps leading to struvite stone formation and identify avenues preventing them. In addition, we are focusing on studying struvite formation in varying urinary compositions to identify urinary components regulating struvite precipitation and stone formation. Overall this work has the potential to identify factors that negatively regulate bacterial colonization and struvite stone formation, improving the efficacy of antibiotic treatment to prevent struvite stone recurrence.

\section{ACKNOWLEDGMENTS}

Erika Espinosa-Ortiz assisted with the study.

\section{REFERENCES}

1. Feldman HA: Rolling stones: the evaluation, prevention, and medical management of nephrolithiasis. Physician Assistant Clin 2016; 1: 127.

2. Uribarri J, Oh MS and Carroll HJ: The first kidney stone. Ann Intern Med 1989; 111: 1006.

3. Bazin D, Andre G, Weil R et al: Absence of bacterial imprints on struvite-containing kidney stones: a structural investigation at the mesoscopic and atomic scale. Urology 2012; 79: 786.

4. Schultz LN, Connolly J, Lauchnor E et al: Struvite stone formation by ureolytic biofilm infections.
In: The Role of Bacteria in Urology. Edited by D Lange and B Chew. Cham, Switzerland: Springer International 2016; pp 41-49.

5. Bichler $\mathrm{KH}$, Eipper $\mathrm{E}, \mathrm{Naber} \mathrm{K}$ et al: Urinary infection stones. Int J Antimicrob Agents 2002; 19: 488.

6. Broomfield RJ, Morgan SD, Khan A et al: Crystalline bacterial biofilm formation on urinary catheters by urease-producing urinary tract pathogens: a simple method of control. J Med Microbiol 2009; 58: 1367
7. Englert KM, McAteer JA, Lingeman JE et al: High carbonate level of apatite in kidney stones implies infection, but is it predictive? Urolithiasis 2013; 41: 389

8. Jacobsen SM and Shirtliff ME: Proteus mirabilis biofilms and catheter-associated urinary tract infections. Virulence 2011; 2: 460.

9. Lee HP, Leong D and Heng CT: Characterization of kidney stones using thermogravimetric analysis with electron dispersive spectroscopy. Urol Res 2012; 40: 197. 
10. Rao NP, Preminger GM and Kavanagh JP: Urinary Tract Stone Disease. London: Springer London 2011.

11. Finlayson B: The concept of a continuous crystallizer. Its theory and application to in vivo and in vitro urinary tract models. Invest Urol 1972; 9: 258.

12. Chow K, Dixon J, Gilpin $S$ et al: A stone farm: development of a method for simultaneous production of multiple calcium oxalate stones in vitro. Urol Res 2004; 32: 55.

13. Choong SK, Wood S and Whitfield HN: A model to quantify encrustation on ureteric stents, urethral catheters and polymers intended for urological use. BJU Int 2000; 86: 414.

14. Gorman SP, Garvin CP, Quigley F et al: Design and validation of a dynamic flow model simulating encrustation of biomaterials in the urinary tract. J Pharm Pharmacol 2003; 55: 461.

15. Shaw GL, Choong SK and Fry C: Encrustation of biomaterials in the urinary tract. Urol Res 2005; 33: 17.

16. Stickler DJ and Morgan SD: Modulation of crystalline Proteus mirabilis biofilm development on urinary catheters. J Med Microbiol 2006; 55: 489

17. Goeres DM, Loetterle LR, Hamilton MA et al: Statistical assessment of a laboratory method for growing biofilms. Microbiology 2005; 151: 757.
18. Brooks T and Keevil CW: A simple artificial urine for the growth of urinary pathogens. Lett Appl Microbiol 1997; 24: 203.

19. Jung D, Biggs $H$, Erikson $J$ et al: New colorimetric reaction for endpoint, continuous-flow, and kinetic measurement of urea. Clin Chem 1975; 21: 1136

20. Prywer J, Torzewska A and Plocinski T: Unique surface and internal structure of struvite crystals formed by Proteus mirabilis. Urol Res 2012; 40: 699 .

21. Holling N, Dedi C, Jones CE et al: Evaluation of environmental scanning electron microscopy for analysis of Proteus mirabilis crystalline biofilms in situ on urinary catheters. FEMS Microbiol Lett 2014; 355: 20.

22. Clapham L, McLean RJ, Nickel JC et al: The influence of bacteria on struvite crystal habit and its importance in urinary stone formation. J Cryst Growth 1990; 104: 475

23. Grases F, Costa-Bauza A and Garcia-Ferragut L: Biopathological crystallization: a general view about the mechanisms of renal stone formation. Adv Colloid Interface Sci 1998; 74: 169

24. Sun J, Chen L, Wang $X$ et al: Synthesis of struvite crystals by using bacteria Proteus mirabilis. Synthesis React Inorg Metal-Organic Nano-Metal Chem 2012; 42: 445.
25. Parkhurst DL and Appelo C: User's Guide to PHREEQC (Version 2): A Computer Program for Speciation, Batch-Reaction, One-Dimensional Transport, and Inverse Geochemical Calculations. Water-Resources Investigations Report 99-4259 Washington, D.C.: United States Geological Survey 1999

26. Johri N, Cooper B, Robertson W et al: An update and practical guide to renal stone management Nephron Clin Pract 2010; 116: c159.

27. Costerton JW, Stewart PS and Greenberg EP: Bacterial biofilms: a common cause of persistent infections. Science 1999; 284: 1318.

28. Wilks SA, Fader MJ and Keevil CW: Novel insights into the Proteus mirabilis crystalline biofilm using real-time imaging. PLoS One 2015 10: e0141711.

29. Jansen $A M$, Lockatell $V$, Johnson $D E$ et al: Mannose-resistant Proteus-like fimbriae are produced by most Proteus mirabilis strains infecting the urinary tract, dictate the in vivo localization of bacteria, and contribute to biofilm formation. Infect Immun 2004; 72: 7294.

30. Jansen AM, Lockatell CV, Johnson DE et al: Visualization of Proteus mirabilis morphotypes in the urinary tract: the elongated swarmer cell is rarely observed in ascending urinary tract infection. Infect Immun 2003; 71: 3607. 